\title{
Estrogen Secreting Adrenal Adenocarcinoma in an 18-Month- old Boy: Aromatase Activity, Protein Expression, mRNA and Utilization of Gonadal Type Promoter
}

\author{
ToмoyUki WATANABE, ToshiyUki YASUDA, Hiromasa NODA**, KYoKo WADA, Itsuro KAZUKAWA, \\ TOMOHIRo SOMEYA, KANSHI MINAMITANI, MASANORI MINAGAWA, KUNIo WATAKI, \\ TADASHI MATSUNAGA*, NAOMI OHNUMA*, YoIChI KOHNO AND NobUhIRo HARADA*** \\ Department of Pediatrics, Chiba University School of Medicine, Chiba 260-8670, Japan \\ * Department of Pediatric Surgery, Chiba University School of Medicine, Chiba 260-8670, Japan \\ ** Department of Pediatrics, Funabashi Central Hospital, Funabashi 273-0021, Japan \\ *** Department of Biochemistry, Fujita Health University, Toyoake 470-1192, Japan
}

\begin{abstract}
We examined clinical, endocrinological and molecular biological aspects of an estrogen-secreting adrenal carcinoma in an 18-month-old male to clarify the pathogenesis of this condition. An 18-month-old boy was referred for evaluation of progressive bilateral gynecomastia and appearance of pubic hair. The patient had elevated plasma estradiol $(349 \mathrm{pg} / \mathrm{ml})$ and testosterone $(260 \mathrm{ng} / \mathrm{dl})$ levels that completely suppressed FSH and LH levels, and was subsequently diagnosed with an adrenal tumor on the right side. After removal of a 300-g adenocarcinoma, gynecomastia regressed and essentially normal hormone levels were restored. Aromatase activity in the tumor tissue determined by the ${ }^{3} \mathrm{H}$-water method was $71.0-104.4 \mathrm{pmol} / \mathrm{min} / \mathrm{mg}$ protein. High levels of aromatase protein and mRNA in the tumor tissue were also demonstrated, while neither aromatase activity nor protein was detected in normal adrenal glands. To investigate the regulation of aromatase expression in the adrenal carcinoma, we examined the usage of alternate promoters responsible for aromatase gene transcription. In the present case, the amounts of aromatase mRNA utilizing gonadal types of exon 1c (I.3) and 1d (II) were significantly higher than those that using other exon 1s. This result suggested that the utilization of a gonadal-type exon $1 \mathrm{might}$ be involved in the overproduction of aromatase in estrogen-secreting adrenal carcinoma.
\end{abstract}

Key words: Aromatase, Estrogen, Adrenal, Carcinoma

(Endocrine Journal 47: 723-730, 2000)

\begin{abstract}
AROMATASE cytochrome P-450, also known as estrogen synthetase, is an essential enzyme in the synthesis of estrogens through the aromatization of androgens, and forms an enzymatic complex along with NADPH-P-450 reductase. This enzyme is present in gonadal tissues such as ovary [1] and placenta $[2,3]$, but also in extragonadal tissues such as brain [4] and adipose tissue [5, 6]. However, aromatase expression has not been observed in nor-

Received: May 10, 2000

Accepted: September 13, 2000

Correspondence to: Tomoyuki WATANABE, M.D., Department of Pediatrics, Chiba University School of Medicine, 18-1 Inohana, Chuo-ku, Chiba 260-8670, Japan
\end{abstract}

mal adrenal tissues. Excessive or inappropriate aromatase expression in adrenal carcinoma is associated with abnormally high circulating estrogen levels and/or increased local estrogen concentrations in adrenal tissues. Elevated estrogen levels, which is either systemically delivered or locally produced, promote the growth of hormone-responsive tissues.

The human aromatase gene contains 10 exons spanning at least 70 kilobases and is located on chromosome $15 q 21$, which contains a cluster of P450 genes. Tissue-specific regulation of aromatase mRNA is achieved through the alternate splicing of exon 1 and part of exon 2 , driven by at least five major promoter regions located within the $5^{\prime}$-untranslated region of the gene. Exon 1a (I.1) is uti- 
Table 1. Insulin and GnRH stimulation test

\begin{tabular}{lrrrrrl}
\hline & 0 & 30 & 60 & 90 & 120 & $(\mathrm{~min})$ \\
\hline ACTH $(\mathrm{pg} / \mathrm{ml})$ & 89 & 453 & 178 & 288 & 888 & \\
Cortisol $(\mu \mathrm{g} / \mathrm{dl})$ & 11.4 & 14.1 & 13.8 & 12.9 & 12.9 & \\
BS $(\mathrm{mg} / \mathrm{dl})$ & 87 & 50 & 57 & 62 & 60 & \\
LH $(\mathrm{mIU} / \mathrm{ml})$ & $<0.2$ & 0.4 & 0.6 & 0.4 & 0.4 & \\
FSH $(\mathrm{mIU} / \mathrm{ml})$ & $<0.2$ & 0.7 & 0.7 & 0.6 & 0.6 & \\
\hline
\end{tabular}

lized mainly for aromatase mRNA expression in placenta, 1b (I.4) utilized mainly in skin fibroblasts and fetal liver, and both 1c (I.3) and 1d (II) are utilized in the ovary and prostate, respectively $[7,8]^{*}$. Therefore, tissue and developmentally regulated utilization of alternate exons 1 of aromatase gene allows for a complex regulatory mechanism for the tissue-specific expression of human aromatase.

Mild breast development occurs in 30-65\% of boys during puberty, but is usually a self-limiting condition. However, the development of severe gynecomastia in prepubertal and adolescent boys and young men are very rare and may be the result of an estrogen-secreting carcinoma, or due to the recently reported aberrant $\mathrm{P}-450$ aromatase gene transcription [9], or some other cause. Studies of uterine, ovarian, testicular and adrenal tumors of various types and grades of malignancy have suggested that alternative promoter-usage may be associated with the mechanisms that underlie neoplastic transformation. The clinical, endocrinological and molecular biological aspects of an estrogen-secreting adrenal carcinoma in an 18-month-old male are described.

\section{Subject and Methods}

\section{Subject}

An 18-month-old boy was referred for evaluation of progressive bilateral gynecomastia and appearance

\footnotetext{
* The nomenclature of the various aromatase first exons and corresponding promoters is unsettled. In this manuscript, we use the codes established by Harada et al. [7]; exons 1a, 1b, 1c and 1d, which correspond to promoters PI. 1 (placenta), PI. 4 (adipose tissue), PI. 3 (adipose tissue), and PII (gonads) reported by Simpson et al. [8], respectively. The latter are indicated in parentheses.
}

of pubic hair. He was the product of a normal pregnancy and delivered at term with a birth weight of $2826 \mathrm{~g}$. His mother had neither received drugs nor experienced signs of virilization during gestation and had never employed oral contraceptives. Breast-feeding continued for 10 months. Pubarche started at 6 months of age and was followed by growth of breasts noticed at 18 months. Family history was unremarkable. Physical examination revealed symmetric gynecomastia at Tanner pubertal stage II (TS-II) with definite glandular tissue palpable, facial acne, pubic hair at TS-II and testicular volume of $2 \mathrm{ml}$ bilaterally. Body weight and height were $14.5 \mathrm{~kg}$ (+3.5 S.D.) and $83 \mathrm{~cm}$ (+0.65 S.D.), respectively. Bone age was 3 years and blood pressure $96 / 70$. Magnetic resonance imaging of the abdomen revealed a right adrenal mass $(6 \times 9 \times 10 \mathrm{~cm})$. Chest X-ray was not suggestive of pulmonary metastases.

\section{Endocrine evaluation and treatment}

The patient had elevated plasma estradiol $\left(E_{2}\right)$ $(349 \mathrm{pg} / \mathrm{ml})$, testosterone (T) $(260 \mathrm{ng} / \mathrm{dl})$ and dehydroepiandrosterone sulfate (DHEAS) $(29500 \mathrm{ng}$ $/ \mathrm{ml}$ ), with undetectable gonadotropin levels. Insulin-stimulated levels of ACTH and cortisol, and GnRH-stimulated levels of gonadotrophins were evaluated (Table 1). Basal plasma ACTH level was slightly above the upper normal range, and this value markedly increased after insulin induced hypoglycemia (regular insulin $0.10 \mathrm{U} / \mathrm{kg}$, iv), whereas plasma cortisol levels remained unchanged.

These results suggested that the patient's tumorfree adrenal function might be abnormal. Plasma renin activity (PRA) levels was high $(14.0 \mathrm{ng} / \mathrm{ml} / \mathrm{hr})$ which might also suggest a subclinical adrenal insufficiency. Gonadotropin levels were completely 
suppressed after GnRH injection (100 $\mu \mathrm{g} / \mathrm{m}^{2}$, iv).

The patient underwent exploratory laparotomy with resection of the right adrenal tumor. The weight of the adrenal mass was $300 \mathrm{~g}$. There was no evidence of intraabdominal, paraaortic node, or hepatic metastases. Plasma hormone levels before and after surgery are shown in Table 2. After resection of the tumor, plasma DHEAS, $T$ and $E_{2}$ levels quickly fell and serum cholesterol level became normalized. The tumor was histologically an adenocarcinoma and mitotane therapy was initiated. Postoperatively, the patient was maintained on supportive glucocorticoid therapy, which was stopped 6 months later. Gynecomastia and pubic hair rapidly disappeared. Examinations at the present time have been normal.

\section{Quantity of aromatase activity}

Tumor tissue aromatase activity was determined by the tritiated $\left({ }^{3} \mathrm{H}\right)$-water method as previously reported by Thompson and Siiteri with some modifications [10]. Details of the assay are reported by Watanabe et al. [11]. Human full-term placental microsomal fractions were included as positive controls.

\section{Quantity of aromatase $m R N A$}

Tumor samples were homogenized in 5 volumes of $5 \mathrm{M}$ guanidine thiocyanate containing $5 \mathrm{mM}$ sodium citrate and $0.5 \%$ sodium sarcosyl, and total RNA prepared as described by Chirgwin et al. [12]. Aromatase mRNA was assessed in these samples by RT-PCR as previously described $[7,13]$. Internal standard RNA (0.01 attomole of human aromatase RNA containing a 21-base insertion) and total RNA $(1 \mu \mathrm{g})$ were reverse transcribed at $42^{\circ} \mathrm{C}$ for $40 \mathrm{~min}$ and amplified by PCR for 26 cycles in the presence of a FAM-labeled primer. A FAM-labeled sense primer corresponding to exon 3 and an antisense primer corresponding to exon 5 were used as PCR primers to allow quantitative analysis of aromatase mRNA. Aliquots of the fluorescent PCR products were mixed with $3 \mu$ l GENESCAN-1000 ROX (Applied Biosystems, Foster City, CA), DNA size markers labeled with the fluorescent dye ROX, and analyzed fluorometrically with a Gene Scanner 362. FAM-labeled PCR products showed two peaks corresponding to amplified products of aromatase mRNA and the internal standard RNA at positions approximately 378 and $399 \mathrm{bp}$, respectively. The amount of aromatase mRNA in each sample was calculated from the peak areas of fluorescent products by the internal standard method as previously described [7]. No fluorescent PCR products were detected in the absence of RNA.

\section{Western blot analysis}

Tissue samples were homogenized in 10 volumes ice-cold $0.25 \mathrm{M}$ sucrose containing $20 \mathrm{mM}$ Tris- $\mathrm{HCl}$ (pH 7.5) and $1 \mathrm{mM}$ ethylenediamine tetraacetate us-

Table 2. Plasma hormone levels of a boy with adrenal cancer and gynecomastia

\begin{tabular}{llll}
\hline & $\begin{array}{l}\text { Before } \\
\text { surgery }\end{array}$ & $\begin{array}{l}\text { After } \\
\text { surgery }\end{array}$ & $\begin{array}{l}\text { Normal } \\
\text { range }\end{array}$ \\
\hline $\mathrm{E}_{2}(\mathrm{pg} / \mathrm{ml})$ & 349 & $<10$ & $<10$ \\
$\mathrm{~T}(\mathrm{ng} / \mathrm{dl})$ & 260 & 2 & $3-13$ \\
$\mathrm{DHEAS}(\mathrm{ng} / \mathrm{ml})$ & 29500 & 23 & $59-87$ \\
$\mathrm{ACTH}(\mathrm{pg} / \mathrm{ml})$ & $89\left(888^{* 1}\right)$ & 7.9 & $4.8-50.8$ \\
Cortisol $(\mathrm{ug} / \mathrm{dl})$ & 11.4 & 22.1 & $3.0-21.0$ \\
Aldosterone $(\mathrm{pg} / \mathrm{ml})$ & 135 & 55.9 & $66.4-217.6$ \\
$\mathrm{LH}(\mathrm{mIU} / \mathrm{ml})$ & $<0.2\left(0.6^{* 2}\right)$ & 0.31 & $0.04-0.77$ \\
$\mathrm{FSH}(\mathrm{mIU} / \mathrm{ml})$ & $<0.2\left(0.7^{* 2}\right)$ & 1.08 & $0.18-2.06$ \\
$17-O H P(\mathrm{ng} / \mathrm{ml})$ & 0.6 & & \\
$\mathrm{~T}-\mathrm{cho} .(\mathrm{mg} / \mathrm{dl})$ & 16 & 163 & $115-220$ \\
\hline
\end{tabular}

*1; insulin tolerance test, basal (max)

*2; LH-RH test, basal (max) 
ing a Polytron homogenizer (Brinkmann Instruments, Westbury, NY). Microsomal fractions were prepared by successive centrifugation from the homogenates as previously described [14]. Final microsomal pellets were suspended in a minimum volume of $50 \mathrm{mM}$ Tris- $\mathrm{HCl}$ (pH 7.5) containing 20\% glycerol and $1 \mathrm{mM}$ ethylenediamine tetraacetate. Protein content was estimated using the BCA protein assay (Pierce Chemical Co., Rockford, IL), with BSA as a standard. SDS-PAGE was performed according to the procedure of Laemmli [15]. Microsomal proteins were loaded on $9 \%$ SDS polyacrylamide gels. After electrophoresis, proteins were transferred to nitrocellulose membranes, immunoreacted with rabbit polyclonal antibody $[16,17]$ raised against human placental aromatase and visualized with alkaline phosphatase-conjugated goat antirabbit IgG (Bio-Rad Laboratories, Richmond, CA).

\section{Analysis of alternative exon 1 usage in aromatase mRNA}

The utilization of alternative aromatase gene exon 1 usage was determined by RT-PCR using sense primers specific for exons 1a (I.1), 1b (I.4), 1c (I.3) and 1d (II) and a fluorescent dye-labeled antisense exon 3-specific primer as described previously $[7,13$, 18]. Harada et al. previously reported that exon 1a (I.1) was utilized in human placenta, 1b (I.4) in skin fibroblasts and fetal liver, 1c (I.3) in ovary and 1d (II) in prostate. Fluorescent PCR products were analyzed with a 362 Gene Scanner (Perkin-Elmer Corp.). Aromatase mRNAs transcribed from exons 1c (I.3) and 1d (II) yielded PCR products corresponding to 357 and $371 \mathrm{bp}$, respectively. Genescan-1000 ROX was used as an internal size standard as described above.

\section{Results}

\section{Aromatase activity in the tumor}

Very high levels of aromatase activity were observed in microsomes obtained from tumor tissue (71.0-104.4 $\mathrm{pmol} / \mathrm{min} / \mathrm{mg}$ protein), which were not detected in normal adrenal tissues.

\section{Aromatase $m R N A$ in the tumor}

Aromatase mRNA levels in the tumor (18.021.4 attomoles $(\mathrm{amol}) / \mu \mathrm{g}$ RNA) were significantly increased compared to undetectable levels in normal adrenal tissues.

\section{Aromatase protein expression in the tumor}

To demonstrate whether tumor aromatase expression levels reflected protein levels, Western blotting analysis of aromatase in adrenal cancer and human placenta tissues was performed. Fig. 1 shows an immunoblot of the tumor and human placenta samples with anti-human aromatase antibody. Microsomes from both tumor and human placenta samples gave single immunoreactive protein bands corresponding to 51,000 dalton molecular weight, which was consistent with the molecular weight of purified human aromatase [19].

\section{Preferential usage of multiple exons 1 in tumor aromatase $\mathrm{mRNA}$}

RT-PCR was used to determine which types of

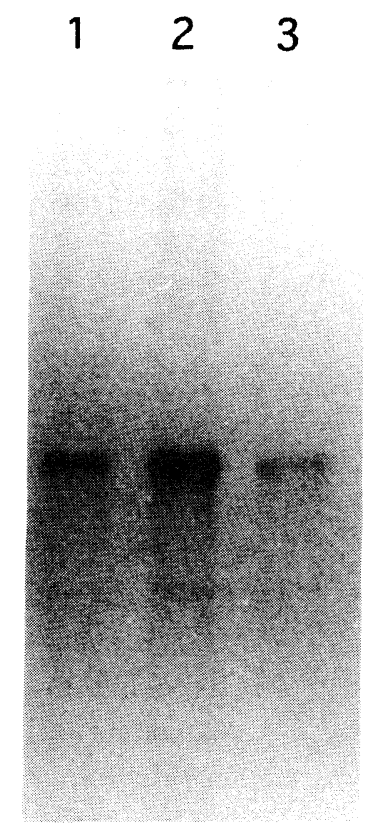

Fig. 1. Western blot analysis of aromatase. Lane 1, adrenal microsomes from the adrenal tumor; Lane 2, microsomes from healthy control placenta; Lane 3, purified aromatase. In normal adrenal glands, aromatase was not deteced (data not shown). 


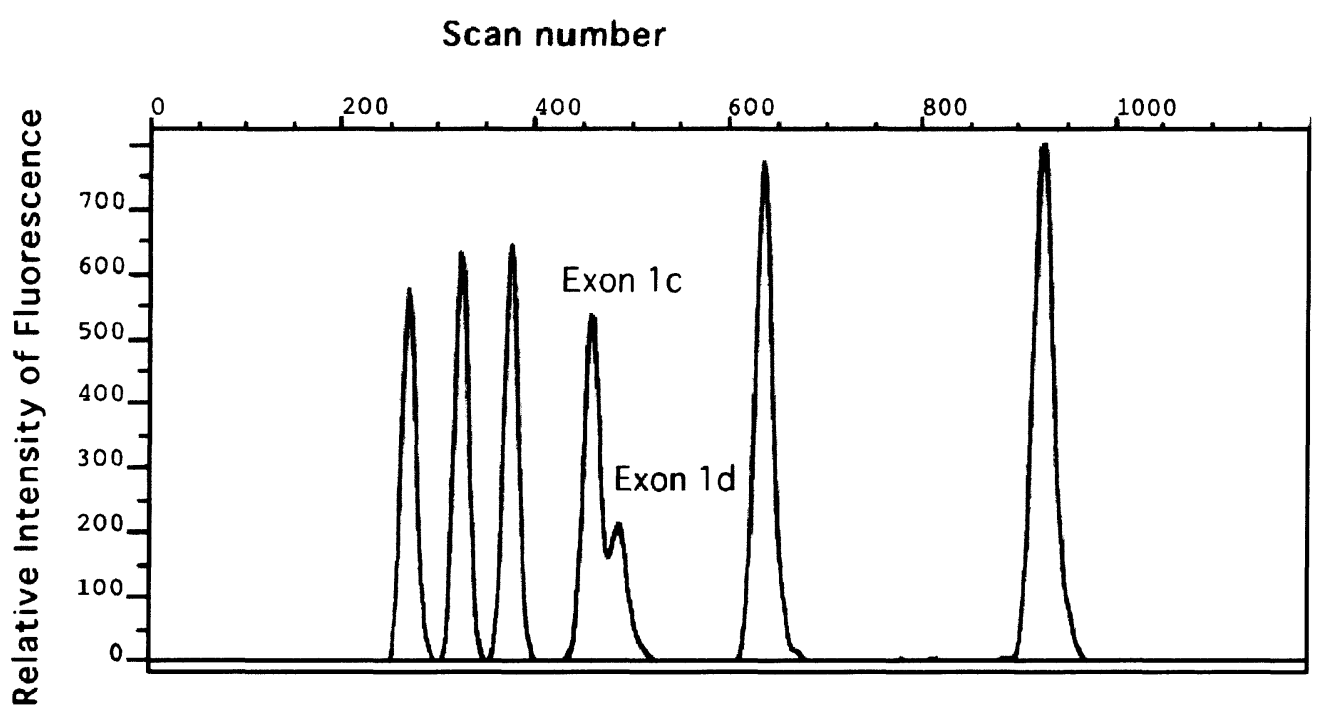

Fig. 2. RT-PCR analysis showing utilization of alternate exon 1 sequences of the human aromatase gene in an adrenal tumor. The GENESCAN-1000 ROX internal size standards produced five peaks, corresponding to 263, 291, 318, 439 and $557 \mathrm{bp}$.

multiple exons 1 and promoters were used in the tumor. Relative preference of exons 1 utilization was assessed fluorometrically as shown in Fig. 2. Exon 1c (I.3) and 1d (II) were exclusively used in the tumor aromatase mRNA.

\section{Discussion}

This report presents a feminizing adrenocortical carcinoma in an 18-month-old boy with gynecomastia and virilization. As the patient had highly elevated $\mathrm{E}_{2}$ levels, we examined aromatase activity, aromatase protein, and tumor-specific aromatase gene promoter usage. To our knowledge, the patient was the youngest reported with an estrogen producing adrenal tumor [20-35], and constituted the second report describing the preferential usage of alternative exons 1 of aromatase gene in adrenal tumors (Table 3).

The patient had a relatively high basal ACTH and PRA, an exaggerated ACTH response but no cortisol response to insulin induced hypoglycemia. This indicated that the patient's normal adrenal gland did not secrete cortisol and aldosterone normally. An extremely low cholesterol level in this patient was apparently due to the uptake of cholesterol by the $300 \mathrm{~g}$ adrenal tumor as an initial substrate of steroid biosynthesis. This is supported by the observation that the low cholesterol level before surgery returned to normal after excision of the tumor. Since $80 \%$ of adrenal steroidgenesis is accounted for by the uptake of plasma cholesterol, the patient's extremely low cholesterol level, due to the excessive uptake of cholesterol by the adrenal tumor, may have been the cause of the adrenocortical insufficiency in the normal adrenal gland. This is the fourth reported case of an association between hypocholesterolemia and adrenal tumors, and the first accompanied by an estrogen secreting tumor (Table 3).

DHEA, the major adrenal androgen, is converted to androstendione and then testosterone, both of which are substrates for aromatase, which produces estrogen. However, it has not been directly demonstrated that estrogens are synthesized by normal adrenal glands. In this patient, circulating $\mathrm{E}_{2}$ levels were 300-400 times higher than in normal subjects.

The patient had higher DHEA-S levels than those observed in previously reported estrogen-producing adrenal tumors. As the high levels of estrogens and testosterone, and the low levels of gonadotoropins promptly returned to normal after removal of the carcinoma, we concluded that the massive amounts of $\mathrm{E}_{2}$ and testosterone were secreted directly by the adrenal tumor. This hypothesis was supported by the demonstration of aberrant aromatase expression in the adrenal tumor. The tumor-expressed aromatase had a very high level of activity at 71.0- 
Table 3. Summary of reported cases of estrogen secreting adrenal tumor

\begin{tabular}{|c|c|c|c|c|c|c|c|}
\hline Sex/Age & A & $\mathbf{P}$ & E2 & DHEAS & $\begin{array}{l}\text { Clinical } \\
\text { presentation }\end{array}$ & Ref) & \\
\hline $\mathrm{M} / 48 \mathrm{y}$ & & & 367 & 970 & gynecomastia & Boyar & (20) \\
\hline M/27 y. & & & 250 & 1810 & gynecomastia & Boyer & (20) \\
\hline M/43 y. & & & 132 & 7800 & recurrent carcinoma & Nogeire & (21) \\
\hline $\mathrm{F} / 21 \mathrm{~m}$ & & & 170 & 14080 & breast enlargement & Wohltmann & (22) \\
\hline $\mathrm{M} / 37 \mathrm{y}$. & & & 300 & & gynecomastia & Nishiki & (23) \\
\hline F/ $6 y$ & & & 330 & 3100 & breast enlargement & Drop & (24) \\
\hline M/ $6 y$. & & & $40-56$ & 3100 & gynecomastia & Itami & (25) \\
\hline M/48 y. & & & 72 & 1505 & gynecomastia & Seta & (26) \\
\hline $\mathrm{F} / 29 \mathrm{y}$ & & & 105 & 6600 & amenorrhea/hirsutism & Ho Yuen & (27) \\
\hline $\mathrm{M} / 48 \mathrm{y}$. & & & 7.9 & & gynecomastia & Mersey & (28) \\
\hline $\mathrm{M} / 58 \mathrm{y}$. & & & 208 & & gynecomastia & Saadi & (29) \\
\hline $\mathrm{F} / 6 \mathrm{y}$ & & & 30 & 5233 & virilization & McKenna & (30) \\
\hline M/33 y. & & & 62 & 3727 & Cushing/gynecomastia & McKenna & (30) \\
\hline $\mathrm{F} / 63 \mathrm{y}$ & & & 300 & 2630 & Cushing/vaginal bleeding & Singer & (31) \\
\hline $\mathrm{M} / 45 \mathrm{y}$ & & & 69 & 18300 & gynecomastia & Zayed & (32) \\
\hline M/19y. & 3.6 & & 1910 & 4.7 (DHEA) & gynecomastia & Kimura & (33) \\
\hline $\mathrm{F} / 65 \mathrm{y}$ & 2.0 & & 81 & w.n.1 & vaginal bleeding & Goto & (34) \\
\hline M/29y. & 4.2 & G & 515 & 463 & gynecomastia & Young & (35) \\
\hline $\mathrm{M} / 18 \mathrm{~m}$ & $71-104.4$ & G & 349 & 29500 & gynecomastia & Watanabe & \\
\hline
\end{tabular}

A; aromatase activity (pmol/min/mg protein), P; promoter type, G; gonadal type, w.n.l; within normal limit, E2; estradiol $(\mathrm{pg} / \mathrm{ml})$, DHEAS; dehydroepiandrosterone sulfate $(\mathrm{ng} / \mathrm{ml})$

$104.4 \mathrm{pmol} / \mathrm{min} / \mathrm{mg}$ protein, equivalent to that found in full-term human placenta, whereas no aromatase activity was detected in normal adrenals. The high aromatase levels in the tumor tissue were also examined by investigating aromatase protein and mRNA levels, which were undetectable in normal adrenal glands.

We demonstrated that the aromatase gene in the adrenal tumor tissue utilized the gonadal type exons 1c (I.3) and 1d (II). Tissue-specific expression of aromatase is regulated through alternative use of multiple exons 1 and promoter [7, 36]. In fact, each promoter region has been shown to contain binding sites for tissue-specific transcription-regulatory factors [37]. Recently, a switching of the alternative exons 1 was found under pathological conditions [38,
39]. A switching from exon $1 \mathrm{~b}$ to exons $1 \mathrm{c}$ or $1 \mathrm{~d}$ was often observed in association with elevated expression of aromatase in breast cancer tissues [40]. Similar observation was also reported in the tumors of endometrium, ovary, liver, and colon [11, 13, 41]. As reported in breast cancer tissues [42], recruitment of tissue-specific transcription-regulatory factors (1bSEBP) to binding sites (1bSE) in the promoter of exon $1 \mathrm{~b}$ seems to be interfered with when various factors (i.e. PGE2)/cytokines (i.e. IGF-I, IGF-II, IL-1, and IL-6) were secreted from host and tumor cells [43], and consequently, a switching would occur. The expression of aromatase in the present case of adrenal adenocarcinoma might be caused by a similar molecular mechanism. 


\section{References}

1. McNatty KP, Baird DT, Bolton A, Chambers P, Corker CS, McLean H (1976) Concentrations of oestrogens and androgens in human ovarian venous plasma and follicular fluid throughout the menstrual cycle. J Endocrinol 71: 77-85.

2. Thompson EA Jr, Siiteri PK (1974) The involvement of human placental microsomal cytochrome P450 in aromatization. J Biol Chem 249: 5373-5378.

3. Ryan KJ (1959) Biological aromatization of steroids. J Biol Chem 234: 268-272.

4. Naftolin F, Ryan KJ, Davies IJ, Reddy VV, Flores F, Petro Z, Kuhn M, White RJ, Takaoka Y, Wolin L (1975) The formation of estrogen by central neuroendocrine tissues. Recent Prog Horm Res 31: 295319.

5. Grodin JM, Siiteri PK, MacDonald PC (1973) Source of estrogen production in postmenopausal women. $J$ Clin Endocrinol Metab 36: 207-214.

6. Ackerman GE, Smith ME, Mendelson CR, MacDonald PC, Simpson ER (1981) Aromatization of androstenedione by human adipose tissue stromal cells in monolayer culture. J Clin Endocrinol Metab 53: 412-417.

7. Harada N, Utsumi T, Takagi Y (1993) Tissue-specific expression of the human aromatase cytochrome P450 gene by alternative use of multiple exons 1 and promoters, and switching of tissue-specific exons 1 in carcinogenesis. Proc Natl Acad Sci USA 90: 1131211316.

8. Bulun SE, Economos K, Miller D, Simpson ER (1994) CYP19 (aromatase cytochrome P450) gene expression in human malignant endometrial tumors. J Clin Endocrinol Metab 79: 1831-1834.

9. Stratakis CA, Vottero A, Brodie A, Kirschner LS, DeAtkine D, Lu Q, Yue W, Mitsiades CS, Flor AW, Chrousos GP (1998) The aromatase excess syndrome is associated with feminization of both sexes and autosomal dominant transmission of aberrant P450 aromatase gene transcription. J Clin Endocrinol Metab 83: 1348-1357.

10. Thompson EA Jr, Siiteri PK (1974) Utilization of oxygen and reduced nicotinamide adenine dinucleotide phosphate by human placental microsomes during aromatization of androstendione. J Biol Chem 249: 5364-5372.

11. Watanabe K, Sasano H, Harada N, Ozaki M, Niikura H, Sato S, Yajima A (1995) Aromatase in human endometrial carcinoma and hyperplasia. Immunohistochemical, in situ hybridization, and biochemical studies. Am J Pathol 146: 491-500.

12. Chirgwin JM, Przybyla AE, MacDonald RJ, Rutter WJ (1979) Isolation of biologically active ribonucleic acid from sources enriched in ribonuclease. Bio- chemistry 18: 5294-5299.

13. Kaga K, Sasano H, Harada N, Ozaki M, Sato S, Yajima A (1996) Aromatase in human common epithelial ovarian neoplasms. Am J Pathol 149: 4551.

14. Harada N, Negishi M (1984) Mouse liver testosterone 16 alpha-hydroxylase (cytochrome P-450(16) alpha). Purification, regioselectivity, stereospecificity, and sex-dependent expression. J Biol Chem 259: 12651271.

15. Laemmli UK (1970) Cleavage of structural proteins during the assembly of the head of bacteriophage T4. Nature 227: 680-685.

16. Sasano H, Nagura H, Harada N, Goukon Y, Kimura M (1994) Immunolocalization of aromatase and other steroidogenic enzymes in human breast disorders. Hum Pathol 25: 530-535.

17. Santen RJ, Martel J, Hoagland M, Naftolin F, Roa L, Harada N, Hafer L, Zaino R, Santner SJ (1994) Stromal spindle cells contain aromatase in human breast tumors. J Clin Endocrinol Metab 79: 627-637.

18. Sasano H, Kaga K, Sato S, Yajima A, Nagura H, Harada N (1996) Aromatase cytochrome P450 gene expression in endometrial carcinoma. Br J Cancer 74: 1541-1544.

19. Harada N (1988) Novel properties of human placental aromatase as cytochrome P-450: purification and characterization of a unique form of aromatase. $J$ Biochem 103: 106-113

20. Boyar RM, Nogeire C, Fukushima D, Hellman L, Fishman J (1977) Studies of the diurnal pattern of plasma corticosteroids and gonadotropins in two cases of feminizing adrenal carcinoma: measurements of estrogen and corticosteroid production. J Clin Endocrinol Metab 44: 39-45.

21. Nogeire C, Fukushima DK, Hellman L, Boyer RM (1977) Virilizing adrenal cortical carcinoma. Cancer 40: 307-313.

22. Wohltmann H, Mathur RS, Williamson HO (1980) Sexual precocity in a female infant due to feminizing adrenal carcinoma. J Clin Endocrinol Metab 50: 186-189.

23. Nishiki M, Amano K, Itoh H, Ezaki H, Miyachi $Y$ (1980) Feminizing adrenocortical carcinoma in man. Jpn J Surg 10: 159-163.

24. Drop SL, Bruining GJ, Visser HK, Sippell WG (1981) Prolonged galactorrhoea in a 6-year-old girl with isosexual precocious puberty due to a feminizing adrenal tumor. Clin Endocrinol (Oxf) 15: 37-43.

25. Itami RM, Amundson GM, Kaplan SA, Lippe BM (1982) Prepubertal gynecomastia caused by an adrenal tumor. Diagnostic value of ultrasonography. Am J Dis Child 136: 584-586. 
26. Seta T, Saito Z, Sakato S, Morise T, Hifumi S, Mimo N, Kigoshi T, Ueda K, Nakabayashi H, Takeda R (1983) Case of feminizing adrenocortical tumor. Nippon Naika Gakkai Zasshi 72: 1026-1034.

27. Ho Yuen B, Moon YS, Mincey EK, Li D (1983) Adrenal and sex steroid hormone production by a virilizing adrenal adenoma and its diagnosis with computerized tomography. Am J Obstet Gynecol 145: 164-169.

28. Mersey JH, Ceballos L, Levin P, Busky S (1988) Estrogen-secreting adrenal tumor responsive to ACTH: localization by adrenal venous sampling. South Med J 81: 275-278.

29. Saadi HF, Bravo EL, Aron DC (1990) Feminizing adrenocortical tumor: steroid hormone response to ketoconazole. J Clin Endocrinol Metab 70: 540-543.

30. McKenna TJ, O'Connell Y, Cunningham S, McCabe M, Culliton M (1990) Steroidogenesis in an estrogenproducing adrenal tumor in a young woman: comparison with steroid profiles associated with cortisoland androgen-producing tumors. $J$ Clin Endocrinol Metab 70: 28-34.

31. Singer F (1991) Adrenal carcinoma presenting with postmenopausal vaginal bleeding. Obstet Gynecol 78: 569-570.

32. Zayed A, Stock JL, Liepman MK, Wollin M, Longcope C (1994) Feminization as a result of both peripheral conversion of androgens and direct estrogen production from an adrenocortical carcinoma. $J$ Endocrinol Invest 17: 275-278.

33. Kimura $\mathrm{M}$, Itoh $\mathrm{N}$, Tsukamoto $\mathrm{T}$, Kumamoto $\mathrm{Y}$, Takagi Y, Mori Y (1995) Aromatase activity in an estrogen-producing adrenocortical carcinoma in a young man. J Urol 153: 1039-1040.

34. Goto $T$, Murakami $O$, Sato $F$, Haraguchi $M$, Yokoyama K, Sasano H (1996) Oestrogen producing adrenocortical adenoma: clinical, biochemical and immunohistochemical studies. Clin Endocrinol (Oxf)
45: 643-648.

35. Young J, Bulun SE, Agarwal V, Couzinet B, Mendelson CR, Simpson ER, Schaison G (1996) Aromatase expression in a feminizing adrenocortical tumor. J Clin Endocrinol Metab 81: 3173-3176

36. Mahendroo MS, Means GD, Mendelson CR, Simpson ER (1991) Tissue-specific expression of human P450AROM: the promoter responsible for expression in adipose tissue is different from that utilized in placenta. $J$ Biol Chem 266: 11276-11281.

37. Harada N (1999) Aromatase and intracrinology of estrogen in hormone-dependent tumors. Oncology 57: 7-16.

38. Sasano H, Uzuki M, Sawai T, Nagura H, Matsunaga G, Kashimoto O, Harada N (1997) Aromatase in human bone tissue. J Bone Miner Res 12: 1416-1423.

39. Harada N, Sasano H, Murakami H, Ohkuma T, Nagura H, Takagi Y (1999) Localized expression of aromatase in human vascular tissues. Circ Res 84: 1285-1291.

40. Utsumi T, Harada N, Maruta M, Takagi Y (1996) Presence of alternatively spliced transcripts of aromatase gene in human breast cancer. $J$ Clin Endocrinol Metab 81: 2344-2349.

41. Harada N, Ota H, Yoshimura N, Katsuyama T, Takagi Y (1998) Localized aberrant expression of cytochrome $\mathrm{P} 450$ aromatase in primary and metastatic malignant tumors of human liver. J Clin Endocrinol Metab 83: 697-702.

42. Harada N, Honda S (1998) Molecular analysis of aberrant expression of aromatase in breast cancer tissues. Breast Cancer Res Treat 49: 15-21.

43. Zhao Y, Agarwal VR, Mendelson CR, Simpson ER, Cecil H (1996) Estrogen biosynthesis proximal to a breast tumor is stimulated by PGE2 via cyclic AMP, leading to activation of promoter II of the CYP19 (aromatase) gene. Endocrinology 137: 5739-5742. 